NFS

44,2

134

Received 14 June 2013

Revised 3 September 2013

Accepted 5 September 2013

\section{Nutritional quality evaluation of Whitemouth croaker (Micropogonias furnieri) protein isolate}

\author{
William Renzo Cortez-Vega
}

Laboratory of Bioengineering, Faculty of Engineering, Federal University of Grande Dourados - UFGD, Dourados, Brazil

Irene Rodrigues Freitas

Department of Food Engineering and Technology,

São Paulo State University - UNESP, São José do Rio Preto, Brazil, and

Sandriane Pizato and Carlos Prentice

Laboratory of Food Technology, School of Chemistry and Food, Federal University of Rio Grande - FURG, Rio Grande, Brazil

\begin{abstract}
Purpose - The purpose of this study was to isolate Whitemouth croaker protein by alkaline solubilization process and evaluate their nutritional quality to evaluate the bioavailability of essential amino acids.

Design/methodology/approach - The proximate composition, essential amino acid composition, in vitro digestibility, apparent bioavailability, chemical score of amino acids and SDS-PAGE were determined for the isolated croaker proteins.

Findings - The isolated protein showed a high level of protein 92.21 percent and low amount of lipids 0.57 percent. The protein is rich in lysine and leucine, 108.73 and $96.75 \mathrm{mg} / \mathrm{g}$ protein, respectively. The protein isolate had high digestibility, 94.32 percent, which indicates proper utilization of this protein source, while the tryptophan had lower bioavailability ( $12.58 \mathrm{mg}$ amino acid/mg protein). The high chemical scores were found for the amino acids lysine, methionine + cysteine (6.79 and 5.14). SDS-PAGE of proteins extracted showed appearance of the heavy chain of myosin $(220 \mathrm{kDa})$, actin $(50 \mathrm{kDa})$ and other fractions, with molecular weight between 20 and $50 \mathrm{kDa}$, such as troponin I, C and T. Originality/value - The products obtained from croaker muscle can be incorporated as a high value supplements in human diets. The isolated protein exhibited a high content of essential amino acids and digestibility, indicating that the protein has a high nutritional quality.
\end{abstract}

Keywords Protein, Amino acid, Croaker, In vitro digestibility, Solubilization

Paper type Research paper

\section{Introduction}

Proteins are part of the human diet and their nutritional function is to maintain good mental and physical health. However, this nutritional quality depends largely on its composition in essential amino acids, digestibility and bioavailability, e.g. fish protein generally contains high quality, highly digestible and essential amino acid content that caters for human needs (WHO/FAO/UNU, 2007).

The croaker is one of the most captured species of fish in the South Atlantic coast of \begin{abstract}
Brazil. However, despite the wide availability of this raw material, this species reaches
\end{abstract}
Nutrition \& Food Science Vol. 44 No. 2, 2014 pp. 134-143 (c) Emerald Group Publishing Limited 0034-6659

DOI 10.1108/NFS-06-2013-0070 
the market at lower prices compared with other regional species, especially those of smaller sizes (Bonacina and Queiroz, 2007), thus it is considered a fish of low commercial value. Many efforts have been made both in academia and in industry during recent decades, to recover or isolate protein from fish by-products and under-utilised fish species (Kristinsson et al., 2006). Only little information has been published on utilization of fish protein isolate products (Thorkelsson et al., 2008; Nolsoe and Undeland, 2009).

A new technology has been developed to increase fish-based protein food for human consumption. According to Thorkelsson et al. (2008), this innovation is called the acid and alkali processes or $\mathrm{pH}$-shift method. The process of varying $\mathrm{pH}$ values, including alkaline solubilization, is a tool used to isolate protein from complex sources such as muscle, whole fish and byproducts.

One of the most important technical issues in pH-shift method, according to Kristinsson et al. (2006) is that undesirable materials like skin, bones, microorganisms, cholesterol, membrane lipids, and other contaminants are removed during the first centrifugation stage, although the bones may be removed during mechanical deboning.

The isolated protein generally has good functional and nutritional properties that can be used in a higher value product (Gehring et al., 2011; Tahergorabi et al., 2012). This contribution is very important because of the increasing world population, so there is need to get products that have good nutritional properties (Alu'Datt et al., 2012).

In a study to evaluate the nutritional value of Krill protein isolated by the process of $\mathrm{pH}$ variation, the results showed that the protein has a high quality as the reference protein, casein (Gigliotti et al., 2008; Marmon and Undeland, 2013).

The aim of this study was to determine nutritional value of the protein isolate from Whitemouth croaker (Micropogonias furnieri) and to evaluate the bioavailability of essential amino acids.

\section{Material and methods}

Fish processing

The fish used in this study was the Whitemouth croaker (Micropogonias furnieri). The fish were caught and provided by the fish industry of Rio Grande - RS - Brazil. After capture, the fish were filleted and then minced using a depulper (High Tech, Brazil). The process of capturing and grinding did not exceed $12 \mathrm{~h}$. Then, the process of pH-shift was performed.

\section{Whitemouth croaker (Micropogonias furnieri) protein isolate}

The alkaline version of the process was carried out as described by Freitas et al. (2011) with slight modifications. Minced fish $(800 \mathrm{~g})$ was IKA homogenized at a 1:9 (w/v) ratio with cold $\left(3-4^{\circ} \mathrm{C}\right)$ distilled water for $60 \mathrm{~s}$. The $\mathrm{pH}$ of the homogenates was adjusted to 11.2 by using $1 \mathrm{~N} \mathrm{NaOH}$ and remained under constant stirring for $20 \mathrm{~min}$ with stirrer propeller shaft. Homogenates were centrifuged (sigma 6-15) at 9,000 $\times g$ for $20 \mathrm{~min}$ to remove the insoluble materials. The alkaline-soluble fraction was collected and adjusted to the isoelectric point of muscle proteins ( $\mathrm{pH} 5.2$ ) by using $1 \mathrm{~N} \mathrm{HCl}$ under constant stirring for $20 \mathrm{~min}$, with controlled temperature $\left(3-4^{\circ} \mathrm{C}\right)$. It was centrifuged under the same conditions as above. The precipitated proteins were collected. The protein isolated obtained was dried by freeze drying for $24 \mathrm{~h}$.
Nutritional quality evaluation 
NFS

44,2

136

\section{Proximate composition}

Moisture, crude protein and crude fat contents were determined according to the methods described by AOAC (1995). Moisture was determined by the oven drying method at $110^{\circ} \mathrm{C}$ for $24 \mathrm{~h}$; for cooked samples total water content was calculated as [100 (total protein + total lipid + total ash)]. Total protein content was determined by the Kjeldahl method and total lipids were evaluated by the Soxhlet method (AOAC, 1995).

In vitro digestibility

The determination of in vitro protein digestibility was performed by enzymatic digestion with pepsin (specific activity of $10^{7} \mu \mathrm{g}$ tyrosine/min/mg prot) in $0.1 \mathrm{~N} \mathrm{HCl}$ and pancreatin (specific activity of $24 \mu \mathrm{g}$ tyrosine/min $/ \mathrm{mg}$ prot) in phosphate buffer $\mathrm{pH}$ 8.0. Concentrations were calculated based on the standard curve of tyrosine, whose concentration ranged between 3 and $11 \mu \mathrm{g} \cdot \mathrm{mL}^{-1}$ (Feddern et al., 2008). This method of in vitro digestibility was used to be the most recommended to fish protein.

\section{Determination of amino acids}

The amino acid composition was determined used methodology adapted by Dini et al. (1994) by high performance liquid chromatography (HPLC). In the method employed, the sample underwent the process of acid hydrolysis with $6 \mathrm{~N} \mathrm{HCl}$ containing 0.05 percent mercaptoethanol, it was filtered and injected into the apparatus containing norvaline and sarcosine as primary and secondary standards, respectively. The sample was led to equipment buckets with standard solution containing 90, 225 and 900 micromoles of each amino acid and a bucket containing buffer solution of $0.4 \mathrm{~N}$ sodium borate $\mathrm{pH}$ 10.4 to run a blank. The concentration of tryptophan was determined by the dimethyl amino benzoaldehyde (DAB) method where there was prior hydrolysis with $4 \mathrm{~N} \mathrm{LiOH}$ for $24 \mathrm{~h}$ at $110 \pm 1^{\circ} \mathrm{C}$, necessary to eliminate the hyperchromic effect that the tryptophan peptide displays with DAB. The standard curve of tryptophan was prepared with $0,10,20,30,40,50$ and $60 \mu \mathrm{g} / \mathrm{ml}$ and the samples were read in the spectrophotometer of METRONIC at $600 \mathrm{~nm}$ (Lowry et al., 1951).

SDS-PAGE electrophoresis

Sodium dodecyl sulfate polyacrylamide (SDS-PAGE) was performed according to the method of Laemmli (1970). The characterization of the recovered protein fractions was performed by polyacrylamide gel electrophoresis in presence of sodium dodecyl sulfate. The electrophoretic analysis was performed on a vertical electrophoresis unit (GSR/300STS). SDS-PAGE separation was performed. The gel was prepared with a 12 percent separating gel and a 4 percent gel concentration. The samples were dissolved in $1.5 \mathrm{~mL}$ distilled water to form a solution containing 0.2 percent protein. Samples were thermally denatured at $95^{\circ} \mathrm{C}$ for $4 \mathrm{~min}$ in a solution of b-mercaptoethanol, $0.5 \mathrm{M}$ Tris ( $\mathrm{pH} 6.8)$, glycerol, 10 percent SDS (w/v) and 0.1 percent bromophenol blue $(\mathrm{w} / \mathrm{v})$.

To identify the proteins present in the samples, Bio-Rad marker ladders were used. Bands were revealed with Coomassie Brilliant Blue R-250 (Vetec Química Fina LTDA, Rio de Janeiro, Brazil). The determination of protein fractions was performed by molecular weight. A mixture of standard proteins (BenchMark ${ }^{\mathrm{TM}}$ Protein Ladder, California, USA), ranging in molecular mass from 10 to $220 \mathrm{kDa}$, was used. 
Statistical analysis

The analysis was submitted to variance analysis and comparison of the mean was done by Tukey test, and the analyses were performed in triplicate. The program utilized was one-way ANOVA.

\section{Results and discussion}

Proximate composition

The mean proximate composition values presented by croaker protein isolate (Micropogonia furnieri) are showed in Table I. The results of this study for protein are similar to that found by Batista $e$ al. (2007). These authors found 92 percent sardine protein recovered by the process of solubilization at alkaline $\mathrm{pH} 12$. Fontana et al. (2009) obtained 97.7 percent of protein in protein concentrate obtained at $\mathrm{pH} 10.8$ solubilization and found 92.04 percent from recovered catfish muscle protein by alkaline process.

Was found in this study, 0.57 percent of lipid content in Whitemouth croaker protein isolate. This result agree with Nolsoe and Undeland (2009) and agree too with Batista et al. (2007) they found 0.49 percent of lipids in alkaline solubilization process for the isolation of muscle proteins. This shows that an alkaline solubilization process is effective for removing lipids, and consequently it may significantly contribute to the reduction of lipid oxidation, increasing product stability.

On the other hand, the results of this work disagree with the results found by Tadpitchayangkoon and Yongsawatdigul (2009) and Fontana et al. (2009), because these authors have found values for lipids of 0.98 and 1.1 percent, respectively.

With Chaijan et al. (2010) 0.3 percent of the lipids obtained, was retained in the muscle after it was processed with alkaline-aided treatment. The same authors confirm that the removable quantity of lipids is connected to factors such as the lipid content of the raw materials or the viscosity of the homogenate in the adjusted $\mathrm{pH}$. Hultin $e t$ al. (2005) also have confirmed that lipids can be effectively removed in $\mathrm{pH}$-shift processes. Lipid-soluble toxins such polychlorinated biphenyls are removed and cholesterol levels are also reduced.

The ash content of this work was 1.32 percent, being higher than that found by Tadpitchayangkoon and Yongsawatdigul (2009) and Fontana et al. (2009) who found 0.86 and 1.1 percent, respectively. The high concentration of ash present in this work is due to the accumulation of $\mathrm{NaCl}$, due to the adjustment of the $\mathrm{pH}$ during protein isolate extraction process (Kristinsson and Rasco, 2000). However, Taskaya et al. (2009) obtained 3.80 percent ash in the protein isolate from whole gutted silver carp solubilized at $\mathrm{pH}$ 11.5. The same authors found 1.73 percent fat and 93.51 percent protein.

\section{Profile of amino acids}

The nutritional value of food depends on the type and amount of amino acids available for body functions (El-Beltagy and El-Sayed, 2012). According to Chen et al. (2007) the process of alkaline solubilization showed higher content of essential acids.

\begin{tabular}{lcccc}
\hline Sample & Moisture (\%) & Protein $(\%)$ & Crude fat $(\%)$ & Ash (\%) \\
\hline Croaker protein isolate & $3.85 \pm 0.08$ & $92.21 \pm 0.15$ & $0.57 \pm 0.09$ & $1.32 \pm 0.13$
\end{tabular}

Note: Average and standard deviation calculated from triplicate analyses
Nutritional quality evaluation

137 
NFS

44,2

138

The content of essential amino acids of protein isolates is within the values required by FAO/WHO (1990) for infants. The content of essential amino acids is listed in Table II.

In this study, the sample of protein isolate exceeded the requirement level of threonine which is ( $43 \mathrm{mg}$ of amino acid/g protein) and isoleucine (46 mg of amino acid/g protein) for infants, while in the analyzed work 44 and $57 \mathrm{mg}$ of amino acid/g protein were obtained for the amino acids threonine and isoleucine, respectively. The amino acids present in greater quantities were lysine (109 $\mathrm{mg}$ of amino acid/g protein) and leucine ( $97 \mathrm{mg}$ of amino acid/g protein).

Lysine is considered the most important amino acids (Chen et al., 2007), and in this study $109 \mathrm{mg} / \mathrm{g}$ of protein was found, being higher than that found by Sathivel and Bechtel (2008), where the lysine content of arrowtooth protein isolate they obtained by alkaline solubilization process of the amino acid was $101 \mathrm{mg} / \mathrm{g}$ protein. According to other studies it is more than egg yolk protein $(70 \mathrm{mg} / \mathrm{g}$ of protein) that is commonly used as reference protein because of its high nutritional quality (Chen et al., 2007; Taskaya et al., 2009). Taskaya et al. (2009) showed that the total of essential amino acids in carp protein recovered by solubilization at $\mathrm{pH} 11.5$ and was higher and significantly different $(p<0.05)$ than in the initially used raw-material, showing the importance of protein concentration to increase the nutritional value of fish protein.

\section{Digestibility and bioavailability}

A very important parameter for protein nutritional quality is the digestibility. Process-induced changes may however affect this property (Marmon and Undeland, 2013). The structure of a protein, which can be affected by factors such as $\mathrm{pH}$, salt concentration and oxidation, determines the protein functionality and may affect its digestibility.

The Table III presents the in vitro digestibility from the Whitemouth croaker (Micropogonias furnieri) protein isolate.

The digestibility found to the present study was high (94.3 percent). This value is similar to digestibility protein of fish supplied by FAO/WHO/UNU (1985) (94 percent). The process of $\mathrm{pH}$ change causes partially denaturation of protein; this tends to improve the digestibility by facilitating the action of proteolytic digestive enzymes (Castro et al., 2007).

\begin{tabular}{lcc}
\hline Amino acid & $\begin{array}{c}\text { Reported composition } \\
\text { b }\end{array}$ \\
\hline Phe + Tyr & $85 \pm 0.40$ & \\
His & $26 \pm 0.15$ & 19 \\
Ile & $57 \pm 0.35$ & 16 \\
Leu & $97 \pm 0.15$ & 13 \\
Lys & $109 \pm 0.13$ & 19 \\
Met + Cys & $88 \pm 0.11$ & 16 \\
Thr & $44 \pm 0.20$ & 17 \\
Trp & $13 \pm 0.17$ & 9 \\
Val & $55 \pm 0.40$ & 5 \\
& & 13
\end{tabular}

Notes: ${ }^{a}$ Reproduced from FAO/WHO/UNU (1985) where references in this table can be found; baverage and standard deviation calculated from triplicate analyses of a sample 
Table IV presents the apparent bioavailability and the chemical score of amino acid of Whitemouth croaker (Micropogonias furnieri) protein isolate.

Methionine and lysine are considered essential amino acids that are not synthesized by the body and whose dietary intake is of paramount importance. It is observed that higher values were found for these amino acids (82.53 for methionine and 102.57 for lysine) relative to the bioavailability when compared with other amino acids studied.

With respect to the amino acid lysine it presented the highest value for the protein isolate (102.57 $\mathrm{mg}$ amino acid/mg protein) apparent bioavailability. The largest nutritional value of dried protein isolate for the protein dried in an oven indicated that different methods of drying can affect the quality of the protein. Freeze drying resulted in the highest nutritional quality, because the problem of nutritional deterioration is minimized. According to Huda Abdullah and Babji (2000), the drying causes less changes in digestibility than other drying methods and the products seem to be a little more digestible.

The limiting amino acid (histidine) had the lowest score of amino acids $(1.60 \mathrm{mg} / \mathrm{g})$ and the amino acid which had the highest score for protein isolate was lysine $(6.79 \mathrm{mg} / \mathrm{g})$. It can be observed that all the amino acids are present sufficient amounts (according FAO/WHO, 1990), with the exception of histidine.

\section{SDS-PAGE electrophoresis}

The result of the analysis of SDS-PAGE electrophoresis of croaker protein isolate are shown in Figure 1. In croaker protein isolate, electrophoretic profiles typical of myofibrillar proteins are observed, with the appearance of the heavy myosin $(220 \mathrm{kDa})$ and actin $(50 \mathrm{kDa})$ chains. Other fractions with molecular weight between 20 and $50 \mathrm{kDa}$,

\begin{tabular}{lc}
\hline Sample & Digestibility $^{\text {a }(\%)}$ \\
\hline Whitemouth croaker protein isolate & $94.3 \pm 0.12$
\end{tabular}

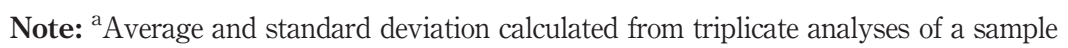

Nutritional

quality evaluation

139
Table III. In vitro digestibility from

Whitemouth croaker (Micropogonias furnieri) protein isolate

\begin{tabular}{lcc}
\hline Amino acids & $\begin{array}{c}\text { Whitemouth croaker protein isolate (mg amino acid/mg protein) } \\
\text { Score of amino acid pattern (FAO/WHO) }\end{array}$ \\
\hline Phe + Tyr & 80.31 & 4.48 \\
His $^{\mathrm{a}}$ & 24.28 & 1.60 \\
Ile & 53.90 & 4.39 \\
Leu & 91.25 & 5.09 \\
Lys & 102.57 & 6.79 \\
Met + Cys & 82.53 & 5.14 \\
Thr & 41.78 & 4.92 \\
Trp & 12.58 & 2.66 \\
Val & 52.34 & 4.26
\end{tabular}

Notes: ${ }^{\mathrm{a}}$ Limiting amino acid; ${ }^{\mathrm{b}}$ apparent bioavailability $=$ amino acid content $(\mathrm{mg} / 100 \mathrm{mg} \mathrm{P}) \times$ in vitro digestibility
Table IV.

Apparent bioavailability and chemical score of amino acid of proteins from Whitemouth croaker (Micropogonias furnieri) protein isolate 
NFS

44,2

\section{0}

Figure 1.

SDS-PAGE

electrophoresis

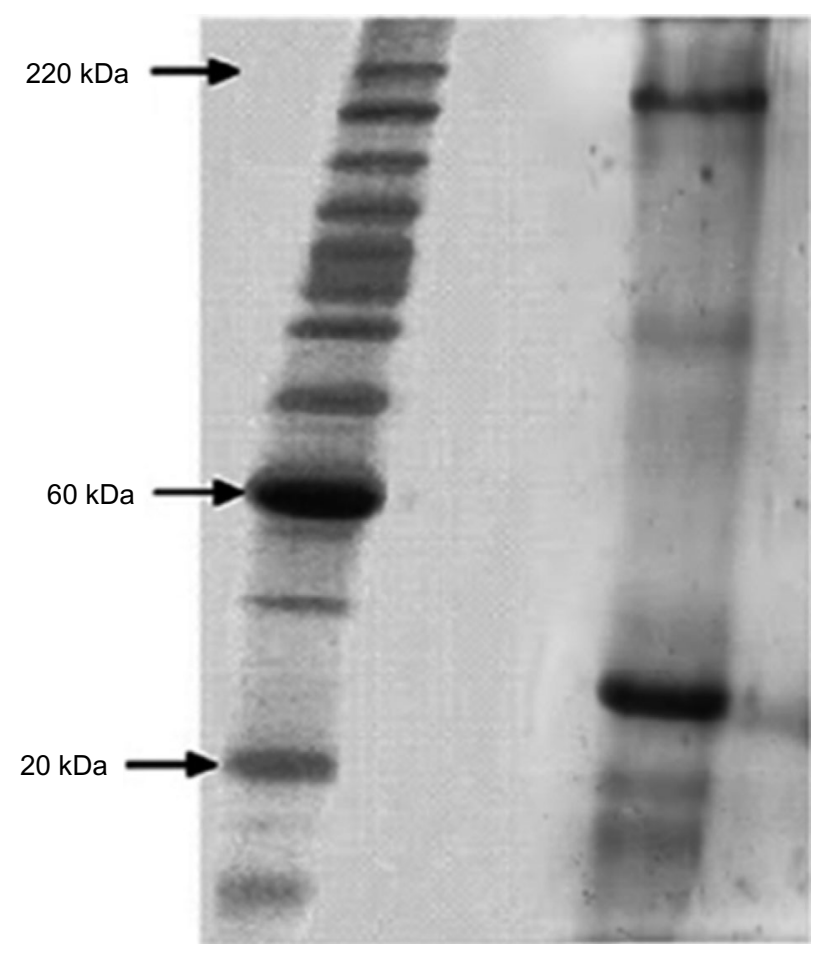

(a)

(b)

Notes: (a) Standard marker; (b) Whitemouth croaker protein isolate

such as troponins I, T and $\mathrm{C}$; myosin light chains as well as $\alpha$ and $\beta$ tropomyosin were also identified. Tongnuanchan et al. (2011) also found heavy myosin chain, actin and troponin proteins as dominant protein of Nile Tilapia (Oreochromis niloticus). The results found by Monterrey-Quintero and Sobral (2000) are also in agreement with the present study, because they also found similar results to this study for the electrophoresis profile of Tilapia (Oreochromis niloticus).

Moreover, Cuq et al. (1995) studied the myofibrillar proteins of sardine (Sardine pilchardus), identified similar bands, but these authors did not separate troponin and tropomyosin in their subunits. In the electrophoretic profile, bands with molecular masses below $20 \mathrm{kDa}$ were also identified. These fractions of smaller masses present in recovered protein may possibly be due to the obtaining process by the method of alkaline solubilization of proteins in that a part of the proteins low molecular weight are hydrolyzed, and therefore appear bands with lower molecular weight.

\section{Conclusion}

The isolated protein exhibited a high content of essential amino acids, indicating that the protein has a relatively high nutritional quality. The value of digestibility is high, 94.3 percent, being considered a great value is in according to the by FAO reported 
digestibility for fish. The limiting amino acid histidine had the lowest score of amino acids; however all of essential amino acids found in the Whitemouth croaker protein isolate were above the levels required. The electrophoretic protein profiles showed typical behavior of myofibrillar proteins. The products obtained from croaker muscle can be incorporated as a high value supplements in human diets.

\section{References}

Alu'Datt, M.H., Rababah, T., Ereifej, K., Alli, I. and Alrababah, M.A. (2012), "Effects of barley flour and barley protein isolate on chemical, functional, nutritional and biological properties of Pita bread", Food Hydrocolloids, Vol. 26, pp. 135-143.

AOAC (1995), Official Methods of Analysis, 16th ed., Association of Official Analytical Chemists, Washington, DC.

Batista, I., Pires, C. and Nelhas, R. (2007), "Extraction of sardine proteins by acidic and alkaline solubilisation", Food Science and Technology International, Vol. 13, pp. 189-194.

Bonacina, M. and Queiroz, M.I. (2007), "Preparation of breaded Whitemouth croaker (Micropogonias furnieri)", Ciência e Tecnologia de Alimentos, Vol. 27, pp. 544-552.

Castro, L.I.A., Vila Real, C.M., Pires, I.S.C., Pires, C.V. and Pinto, N.A.V.D. (2007), "Quinoa (Chenopodium quinoa Willd): in vitro digestibility, development and sensorial analysis of preparations for celiac patients", Alimentos e Nutrição, Vol. 18, pp. 413-419.

Chaijan, M., Panpipat, W. and Benjakul, S. (2010), "Physicochemical and gelling properties of short-bodied mackerel (Rastrelliger brachysoma) protein isolate prepared using alkaline-aided process", Food Bioproducts Process., Vol. 88, pp. 174-180.

Chen, Y.C., Tou, J.C. and Jaczynski, J. (2007), “Amino acid, fatty acid, and mineral profiles of materials recovered from rainbow trout (Oncorhynchus mykiss) processing by-products using isoelectric solubilization/precipitation", Food Chemistry Toxicology, Vol. 72, pp. 528-536.

Cuq, B., Aymard, C., Cuq, J.L. and Guilbert, S. (1995), "Edible packaging films based on fish myofibrillar proteins: formulations and functional properties", Journal of Food Science, Vol. 60, pp. 1369-1374.

Dini, A., Miglioulo, G., Rastrelli, L., Saturnino, P. and Schettino, O. (1994), "Chemical composition of Lepidium meyenii", Food Chemistry, Vol. 49, pp. 347-349.

El-Beltagy, A.E. and El-Sayed, S.M. (2012), "Functional and nutritional characteristics of protein recovered during isolation of chitin from shrimp waste", Food Bioproducts Process, Vol. 90, pp. 633-638.

FAO/WHO (1990), "Protein quality evaluation", Report of a Joint FAO/WHO Expert Consultation, Bethesda, MD, December 1989, FAO, Rome.

FAO/WHO/UNU (1985), "Energy and protein requirements", Report of a Joint FAO/WHO/UNU Expert Consultation, Technical Report Series No. 724, Geneva.

Feddern, V., Pinto, S.S., Nogueira, K.A., Furlong, E.B. and Soares, L.A.S. (2008), "Influence of the composition and fermentation on the physico-chemical and nutritional properties of multimixtures”, Brazilian Journal of Food Technology, Vol. 11, pp. 128-133.

Fontana, A., Centenaro, G.S., Palezi, S.C. and Prentice-Hernández, C. (2009), “Obtainment and evaluation of protein concentrates of Whitemouth croaker (Micropogonias furnieri) processed by chemical extraction", Quimica Nova, Vol. 32, pp. 1-5.

Freitas, I.R., Gauterio, G.V., Rios, D.G. and Prentice, C. (2011), "Functionality of protein isolates from argentine anchovy (Engraulis anchoita) residue obtained using $\mathrm{pH}$ shift processing", Journal of Food Science Engineering, Vol. 1, pp. 374-378.
Nutritional quality evaluation 
NFS

44,2

142

Gehring, C.K., Gigliotti, J.C., Moritz, J.S., Tou, J.C. and Jaczynski, J. (2011), "Functional and nutritional characteristics of proteins and lipids recovered by isoelectric processing of fish by-products and low-value fish: a review", Food Chemistry, Vol. 124, pp. 422-431.

Gigliotti, J.C., Jaczynski, J. and Tou, J.C. (2008), "Determination of the nutritional value, protein quality and safety of krill protein concentrate isolated using an isoelectric solubilization/precipitation technique”, Food Chemistry, Vol. 111, pp. 209-214.

Huda, N., Abdullah, A. and Babji, A.S. (2000), "Nutritional quality of surimi powder from threadfin bream”, Journal Muscle Foods, Vol. 11, pp. 99-109.

Hultin, H.O., Kristinsson, H.G., Lanier Tyre, C. and Park, J.W. (2005), "Process for recovery of functional proteins by PH-shifts", in Park, J.W. (Ed.), Surimi and Surimi Seafood, Taylor \& Francis, Boca Raton, FL, pp. 107-139.

Kristinsson, H.G. and Rasco, B.A. (2000), "Fish protein hydrolysates: production, biochemical, and functional properties", Food Science and Nutrition, Vol. 40, pp. 43-81.

Laemmli, U.K. (1970), "Cleavage of structural proteins during the assembly of the head of bacteriophage T4", Nature, Vol. 227, pp. 680-685.

Lowry, O.H., Rosebough, N.J., Farr, A.L. and Randall, R.J. (1951), "Protein measurement with the Folin phenol reagent", Journal of Biology and Chemistry, Vol. 193, pp. 265-275.

Marmon, S.K. and Undeland, I. (2013), "Effect of alkaline pH-shift processing on gastrointestinal digestion of herring (Clupea harengus) fillets", Food Chemistry, Vol. 138, pp. 214-219.

Monterrey-Quintero, E.S. and Sobral, P.J.A. (2000), "Extraction and properties of nile tilapia myofibrillar proteins for edible films", Pesquisa Agropecuária Brasileira, Vol. 35, pp. 179-189.

Nolsoe, H. and Undeland, I. (2009), "The acid and alkaline solubilization process for the isolation of muscle proteins", Food Bioprocess Technology, Vol. 2, pp. 1-27.

Sathivel, S. and Bechtel, P.J. (2008), "A comparison of physical and rheologic properties of arrowtooth flounder protein made using three different extracting processes", Journal of Food Biochemistry, Vol. 32, pp. 557-575.

Tadpitchayangkoon, P. and Yongsawatdigul, J. (2009), "Comparative study of washing treatments and alkali extraction on gelation characteristics of striped catfish (Pangasius hypophthalmus) muscle protein”, Food Chemistry, Vol. 74, pp. 284-291.

Tahergorabi, R., Beamer, S.K., Matak, K.E. and Jaczynski, J. (2012), "Functional food products made from fish protein isolate recovered with isoelectric solubilization/precipitation", LWT - Food Science and Technology, Vol. 48, pp. 89-95.

Taskaya, L., Chen, Y.C. and Jaczynski, J. (2009), "Functional properties of proteins recovered from silver carp (Hypophthalmichthys molitrix) by isoelectric solubilization/precipitation", LWT - Food Science and Technology, Vol. 42, pp. 1082-1089.

Thorkelsson, G., Sigurgisladottir, S., Geirsdottir, M., Jóhannsson, R., Guérard, F., Chabeaud, A., Bourseau, P., Vandanjon, L., Jaouen, P., Chaplain-Derouiniot, M., Fouchereau-Peron, M., Martinez-Alvarez, O., Le Gal, Y., Ravallec-Ple, R., Picot, L., Berge, J.P., Delannoy, C., Jakobsen, G., Johansson, I., Batista, I. and Pires, C. (2008), "Mild processing techniques and development of functional marine protein and peptide ingredients", in Børresen, T. (Ed.), Improving Seafood Products for the Consumer, Woodhead, Cambridge.

Tongnuanchan, P., Benjakul, S. and Prodpran, T. (2011), "Roles of lipid oxidation and pH on properties and yellow discolouration during storage of film from red tilapia (Oreochromis niloticus) muscle protein", Food Hydrocolloids, Vol. 25, pp. 426-433.

WHO/FAO/UNU (2007), "Protein and amino acid requirements in human nutrition", Report of a Joint WHO/FAO/UNU Expert Consultation, World Health Organization Technical Report Series, Geneva. 


\section{About the authors}

William Renzo Cortez-Vega, $\mathrm{PhD}$, is a Professor of food engineering, Reviewer of different international journals, has experience in food science and technology, with emphasis on food engineering and works on the following topics: fish, film, protein isolate, and nanoclay.

Irene Rodrigues Freitas obtained degree in food engineering, Master degree in engineering and food science, has experience in food science and technology: technology of animal products.

Sandriane Pizato obtained degree in food technology, $\mathrm{PhD}$ student in engineering and food science, Reviewer for international journals, has experience in food science and technology, acting on the following themes: quality meats, biotechnology, food nutrition, fish and lactic acid. Sandriane Pizato is the corresponding author and can be contacted at: sandrianepizato@yahoo.com.br

Carlos Prentice, $\mathrm{PhD}$, is a Professor of food engineering, has experience in food science and technology, with emphasis on food engineering, and works on the following topics: fish, protein isolate, and quality meats.
Nutritional quality evaluation

To purchase reprints of this article please e-mail: reprints@emeraldinsight.com Or visit our web site for further details: www.emeraldinsight.com/reprints 